\title{
Serum insulin-like growth factor-I levels in amyotrophic lateral sclerosis
}

\author{
GLENN D BRAUNSTEIN, ANTIA L REVICZKY \\ From the Department of Medicine, Cedars-Sinai Medical Center-UCLA School of Medicine, Los Angeles, USA
}

SUMMARY The serum concentrations of the myotrophic hormone insulin-like growth factor-I (IGF-I) in 23 patients with amyotrophic lateral sclerosis were not significantly different from those found in the sera of 13 control patients. There was no difference in binding of ${ }^{125}$ I-IGF-I by serum from patients with amyotrophic lateral sclerosis in comparison with that found in the controls. These results indicate that immunoreactive IGF-I concentrations are normal in patients with amyotrophic lateral sclerosis and that such patients do not have significant antibodies binding their endogenous IGF-I.

Several tissue growth factors have been shown to stimulate amino acid uptake and protein synthesis in muscle cells. ${ }^{1-3}$ The muscle atrophy found in some neuromuscular diseases could be due to deficient secretion or action of one or more of these tissue growth factors. One such growth factor, insulin-like growth factor-I (IGF-I, somatomedin-C) has attracted interest because it is the primary growthpromoting mediator of growth hormone action and low levels have been found in some disease states associated with muscle weakness. ${ }^{4}$ Therefore, we examined the serum concentrations of immunoreactive IGF-I in patients with amyotrophic lateral sclerosis.

\section{Materials and methods}

\section{Patients}

Fasting blood samples were obtained from 23 patients with amyotrophic lateral sclerosis and 13 control subjects of similar age. The diagnosis of amyotrophic lateral sclerosis was made by at least one neurologist in all cases, and was based on findings of diffuse muscle weakness, atrophy and fasciculations associated with corticospinal and/or corticobular tract signs without involvement of sensation, coordination, or cognitive function. The diagnosis was supported by electromyography and histochemical studies

Address for reprint requests: Glenn D Braunstein, MD, Room 2119 North Tower, Cedars-Sinai Medical Center, 8700 Beverly Blvd, Los Angeles, CA 90048, USA.

Received 8 August 1986 and in revised form 6 November 1986. Accepted 13 November 1986 of representative skeletal muscles in the majority of patients. All of the amyotrophic lateral sclerosis patients were wellnourished, although 12/23 were non-ambulatory (table). Blood was obtained between 08:00 and 09:00 h following an overnight fast. The serum was rapidly separated from the clot and stored at $-20^{\circ} \mathrm{C}$ until assay.

\section{IGF-I measurements}

IGF-I was measured by two methods with reagents generously supplied by the National Hormone and Pituitary Program (Baltimore, Maryland). The first assay utilised the borosilicate-protamine-free assay system of Furlanetto $\mathrm{et} \mathrm{al}^{5}$ to measure IGF-I in unextracted serum. The second assay used polystyrene tubes containing protamine ${ }^{6}$ to measure IGF-I in acid-ethanol extracted serum samples. As antigen for the radiolabelling, and as standard, a recombinant human IGF-I (Thr 59) analog (Amgen, Thousand Oaks, CA) was used. This analog has been shown to displace ${ }^{125} \mathrm{I}$-IGF-I binding in parallel with human serum-derived somatomedin-C and IGF-I synthesised by solid phase.?

Recovery of added IGF-I in these assays averaged $93.4 \%$ $\pm 14.7 \mathrm{SD}(n=9)$. The within assay coefficients of variation varied between 11 and $12.6 \%$ while the between assay coefficients of variation ranged from 14 to $17 \cdot 7 \%$. All samples were run in duplicate in the same assay, and each assay contained control samples with both high IGF-I (acromegalic serum) and low IGF-I (hypopituitary serum) levels.

\section{Examination of serum samples for IGF-I antibodies}

Two methods were employed to examine serum samples for the presence of antibodies against IGF-I. In the first, $200 \mu$ l of patient's serum, $100 \mu$ l of ${ }^{125}$ I-IGF-I $(10,000 \mathrm{cpm})$ and $200 \mu$ l of phosphate buffer saline, pH 7.8 containing $1 \%$ normal rabbit serum were mixed and incubated overnight at room temperature. Antigen-antibody complexes were pre- 
Table IGF-I levels and anti-IGF-I activity in patients with amyotrophic lateral sclerosis

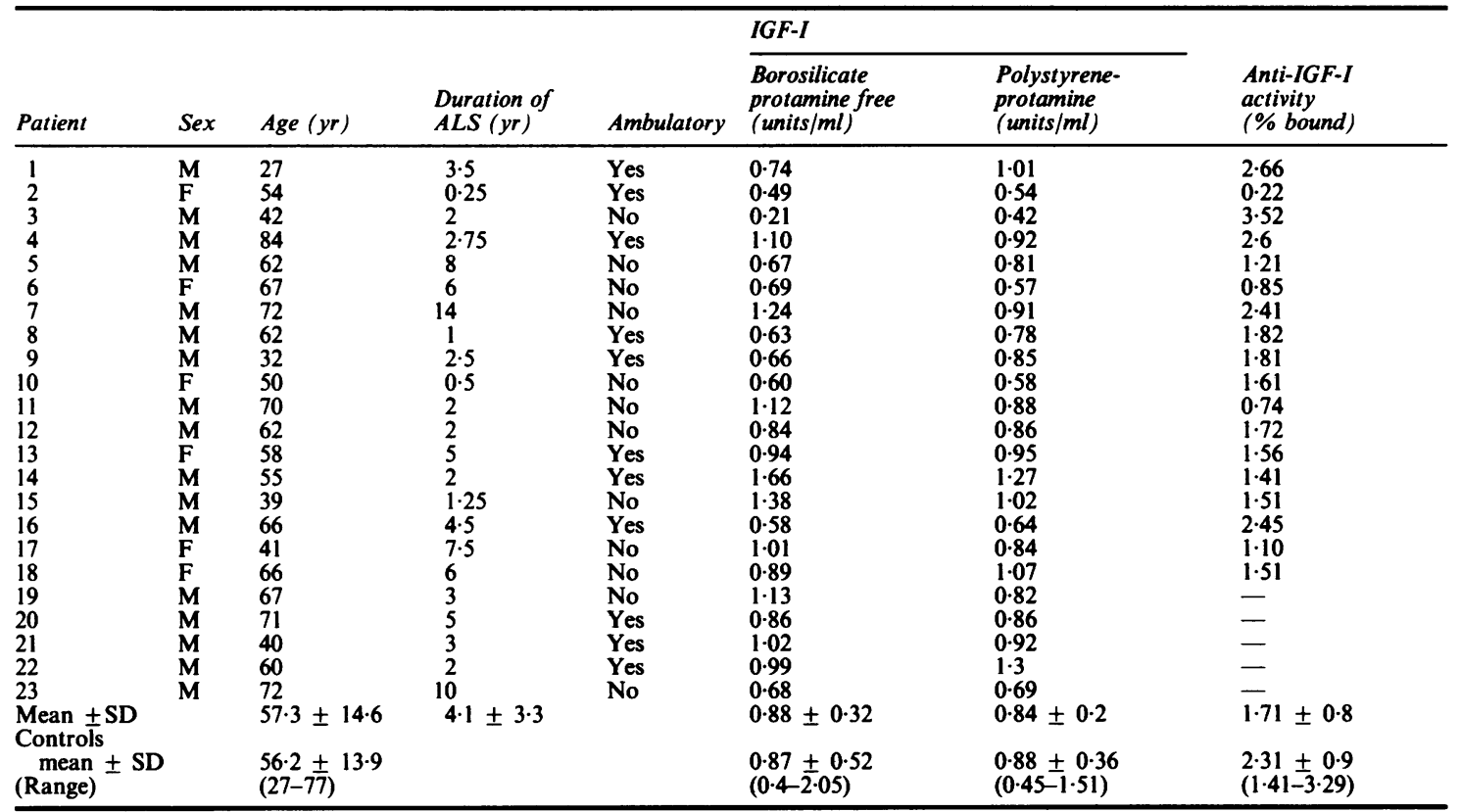

cipitated by the addition of $1 \mathrm{ml} 15 \%$ polyethylene glycol (molecular weight 6,000). After centrifugation, the supernatant was aspirated and the radioactivity present in the precipitates was counted. Nonspecific binding was assessed by the addition of excess unlabelled IGF-I $(100 \mathrm{ng})$ to the assay tubes prior to incubation. The second method employed the same incubation conditions, but differed from the first in that antigen-antibody complexes were precipitated by rabbit anti-human IgG antibody by the addition of Immunobeads (400 mcg anti-IgG per tube) (Bio-Rad Laboratories, Richmond, CA 94804).

\section{Statistics}

IGF-I levels in the patient and control sera were compared by $t$ test and significant differences were considered to be present when $\mathrm{p}<0.05$. Correlations between IGF-I levels measured in unextracted and extracted serum was carried out by least square linear regression analysis.

\section{Results}

The individual and mean serum IGF-I values measured in unextracted and extracted samples in the amyotrophic lateral sclerosis patients and controls are presented in the table. There were no significant differences in IGF-I levels measured by either method between the patients and controls nor was there a sex difference in levels within or between the groups. There were no significant differences between IGF-I concentrations measured by the borosilicate tubeprotamine free buffer assay or the polystyrene-tube protamine buffer method. The correlation of IGF-I values by the two methods in each of the serum samples was highly significant $(r=0.88, p<0.001)$.

Most of the serum samples had less than 3\% specific binding of ${ }^{125}$ I-IGF-I (table). There were no differences between the serum anti-IGF-I binding activity detected by either the polyethylene glycol method or by the Immunobead method (data not shown) between patients with amyotrophic lateral sclerosis and control patients.

\section{Discussion}

The aetiology of amyotrophic lateral sclerosis and the pathogenesis of its abnormalities are unclear. Genetic, toxic, nutritional, hormonal, viral, and immunologic factors have all been implicated in the pathogenesis and progression of the disease ${ }^{8}$ Gurney and co-workers described an antibody in the sera of patients with amyotrophic lateral sclerosis that inhibits sprouting of neurons and reinnervation of skeletal muscle. ${ }^{9}$ This observation has raised the possibility of abnormalities in the action of neuromuscular trophic factors in amyotrophic lateral sclerosis. It is therefore conceivable that abnormalities of other tissue trophic factors may be of importance in the development of the muscular atrophy seen in amyotrophic lateral sclerosis.

The present study demonstrates that serum levels 
of IGF-I in patients with amyotrophic lateral sclerosis are not different from a control population. In addition, we were unable to demonstrate the presence of serum antibodies against IGF-I. These results, however, do not negate the possibility that the biological activity of IGF-I may be abnormal in patients with amyotrophic lateral sclerosis. Impaired biological activity may be due to the presence of circulating inhibitors of IGF-I action, which are known to be present in other chronic diseases. ${ }^{10}$ Alternatively, IGF-I binding to its specific muscle receptor ${ }^{11}$ may be altered, or a postreceptor defect may result in altered IGF-I activity at the level of the muscle and/or nerve cell.

This study was generously supported by the David and Minnie Berk Foundation and the Amyotrophic Lateral Sclerosis Association. We are grateful for the encouragement of $\mathrm{Mr}$ Arthur Levien and Dr Boris Catz and the helpful discussions with Dr Shlomo Melmed. The technical assistance of Ms Lynne Kelley and secretarial help of Ms Helene Zauderer are gratefully acknowledged.

\section{References}

1 Florini JR, Ewton DZ, Evinger-Hodges MJ, et al. Stimulation and inhibition of myoblast differentiation by hormones. In Vitro 1985;20:942-58.

2 Hayashi I, Kobylecki J. Growth of myoblasts in hormone-supplemented serum-free medium. In: Sato GH, Pardee AB, Sirbasku DA, eds. Growth of Cells in
Hormonally Defined Media Cold Spring Harbor Conferences on Cell proliferation Series. 1982;9:857-65.

3 Cheek DB, Graystone JE. Insulin and growth hormone: regulators of growth with particular reference to muscle. Kidney Internat 1978;14:317-22.

4 Phillips LS, Vassilopoulou-Sellin R. Somatomedins. $N$ Engl J Med 1980;302:371-80, 438-45.

5 Furlanetto RW, Underwood LE, Van Wyk JJ, D'Ercole AJ. Estimations of somatomedin-C levels in normals and patients with pituitary disease by radioimmunoassay. J Clin Invest 1977;60:648-57.

6 Furlanetto RW. Pitfalls in the somatomedin-C radioimmunoassay. J Clin Endocrinol Metab 1982;54: 1084-6.

7 Schalch D, Reisman D, Emler C, et al. Insulin-like growth factor I/somatomedin C: comparison of natural, solid phase synthetic and recombinant DNA analog peptides in two radioligand assays. Endocrinology 1984;115:2490-3.

8 Festoff BW, Crigger NJ. Therapeutic trials in amyotrophic lateral sclerosis: a review. In: Mulder DW, ed. The Diagnosis and Treatment of Amyotrophic Lateral Sclerosis. Boston MA: Houghton Mifflin Professional Publishers, 1979:337-69.

9 Gurney ME, Belton AC, Cashman N, Antel JP. Inhibition of terminal axonal sprouting by serum from patients with amyotrophic lateral sclerosis. $N$ Engl $J$ Med 1984;311:933-9.

10 Phillips LS, Unterman TG. Somatomedin activity in disorders of nutrition and metabolism. Clin Endocrinol Metab 1984;13:145-89.

11 Beguinot F, Kahn CR, Moses AC, Smith RJ. Distinct biologically active receptors for insulin-like growth factor I, and insulin-like growth factor II in cultured skeletal muscle cells. J Biol Chem 1985;260:15892-8. 